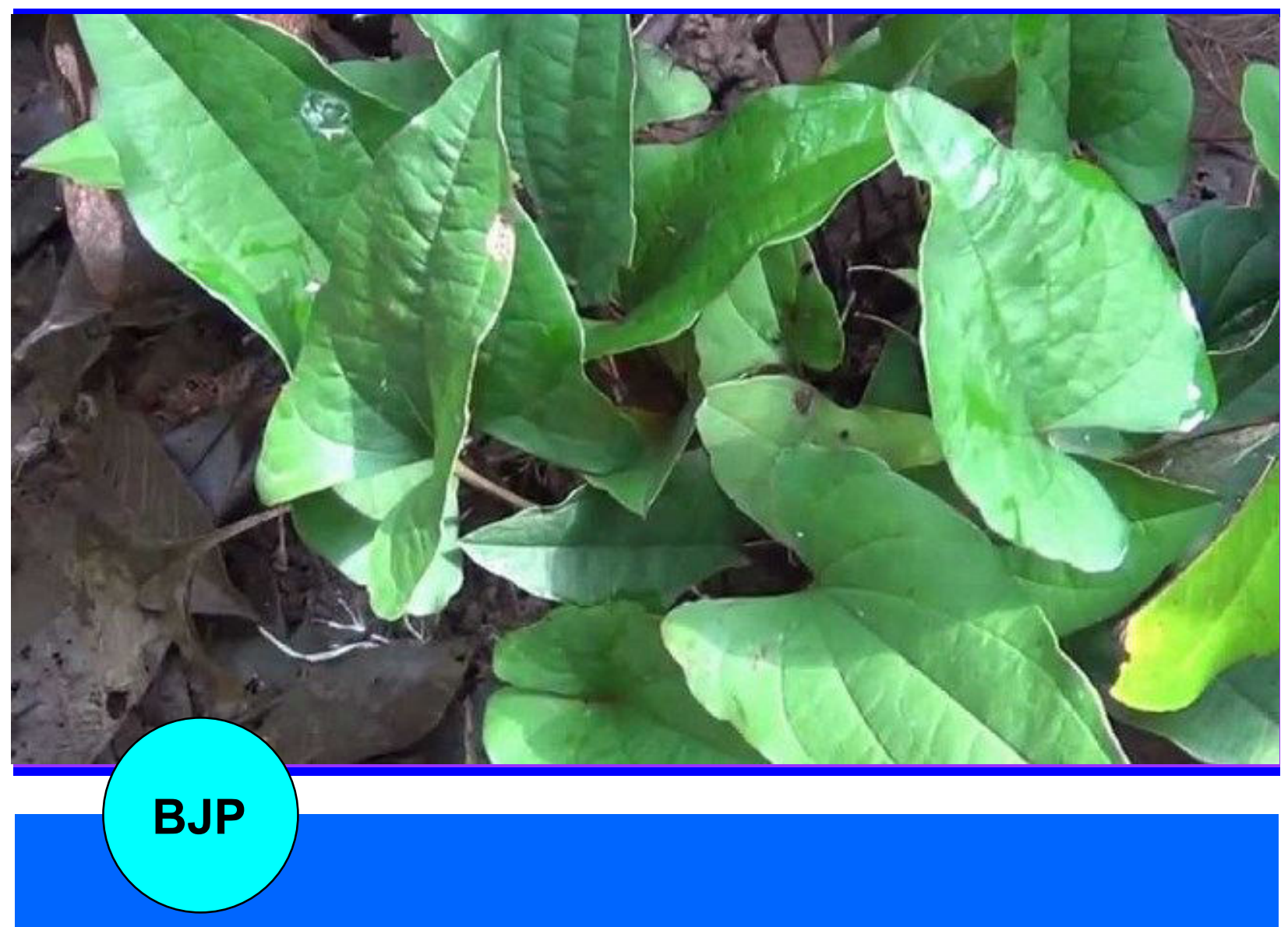

Bangladesh Journal of Pharmacology

Research Article

Cardioprotective effect of Trichopus zeylanicus against myocardial ischemia induced by isoproterenol in rats 
Abstracted/indexed in Academic Search Complete, Agroforestry Abstracts, Asia Journals Online, Bangladesh Journals Online, Biological Abstracts, BIOSIS Previews, CAB Abstracts, Current Abstracts, Directory of Open Access Journals, EMBASE/Excerpta Medica, Google Scholar, HINARI (WHO), International Pharmaceutical Abstracts, Open J-gate, Science Citation Index Expanded and Social Sciences Citation Index

ISSN: $1991-0088$

\title{
Cardioprotective effect of Trichopus zeylanicus against myocardial ischemia induced by isoproterenol in rats
}

\author{
Sivanandham Velavan, S. Selvarani and A. Adhithan
}

P.G. \& Research Department of Biochemistry, Marudhupandiyar College, Bharathidasan University, Thanjavur 613 403, Tamil Nadu, India.

\begin{tabular}{|lr|}
\hline Article Info & \\
\hline Received: & 11 January 2009 \\
Accepted: & 18 April 2009 \\
Available Online: & 20 April 2009 \\
DOI: $10.3329 /$ bjp.v4i2.1824 \\
\\
\\
\\
Cite this article: \\
Velavan S, Selvarani S, Adhithan A. \\
Cardioprotective effect of Trichopus \\
zeylanicus against myocardial ische- \\
mia induced by isoproterenol in rats. \\
Bangladesh J Pharmacol. 2009; $4:$ 88-
\end{tabular}

\section{Abstract}

The cardioprotective effect of Trichopus zeylanicus leaves against isoproterenol -induced myocardial ischemia was studied. Wister strain rats were pretreated with $T$. zeylanicus leaves $(500 \mathrm{mg} / \mathrm{kg}$ body weight) for 28 days and then intoxicated with isoproterenol $(20 \mathrm{mg} / 100 \mathrm{~g}$, i.p. for 2 consecutive days). Cardioprotection was assessed by estimating plasma and heart aspartate aminotransferase, alanine aminotransferase, lactate dehydrogenase, and creatine phosphokinase. Troponin T was estimated in serum, and the levels of thiobarbituric acid reactive substances (TBARS) and reduced glutathione (GSH) were analyzed in heart and plasma. In isoproterenol-treated group, shrinkage of cardiac markers in plasma and elevated lipid peroxidation were accompanied by decreased content of reduced glutathione in heart and plasma. The prior administration of $T$. zeylanicus significantly $(\mathrm{p}<0.001)$ prevented the isoproterenol-induced alterations and restored the cardiac markers. These findings indicate the cardioprotective activity of T. zeylanicus during isoproterenol-induced myocardial ischemia.
\end{abstract}

\section{Introduction}

Trichopus zeylanicus Gaerten Trichopodaceae, is a wild plant, a rare genus, small glabrous herb growing in the Agasthyar hilly forests of Kerala, India. The tribal inhabitants (Kani tribe) of this area call this plant "Arogyappacha" meaning the greener of health, and use this plant as a health tonic and rejuvenator. This information is based on ethno-medico-botanical investigations (Pushpangadan et al., 1988; Evans et al., 2002). Earlier studies on T. zeylanicus in experimental animals have shown several pharmacological activities such as hepatoproctection, anti-ulcer activity, anti-fatigue, antiinflammatory activity, antioxidant activity, aphrodisiac activity, anti-stress, enhancement of swimming performance and immunomodulation (Sharma et al., 1989; Subramoniam et al., 1997; Singh et al., 2001; Singh et al., 2005). In the present study, an attempt has been made to assess the cardio protective effects of $T$. zeylanicus leaves on cardiac function in isoproterenol-induced myocardial infarction in rats.

\section{Materials and Methods}

\section{Chemicals}

Isoproterenol hydrochloride, thiobarbituric acid, 2,4dinitrophenyl hydrazine, and glutathione were purchased from Sigma Chemical, Mumbai. All other reagents and chemicals used in this study were of analytical grade with high purity.

\section{Animals}

Wister strain male albino rats, weighing 100-120 g were selected for the study. The animals were housed individually in polypropylene cages under hygienic and standard environmental conditions $\left(28 \pm 2^{\circ} \mathrm{C}\right.$, humidity 
$60-70 \%, 12$ hours light/dark cycle). The animals were allowed a standard feed and water ad libitum. They were acclimatized to the environment for 1 week prior to experimental use. The study protocol was carried out as per the rules and regulation of the institutional animal's ethics committee.

\section{Plant material and preparation of extract}

T. zeylanicus leaves were collected in the month of April and May from the Agasthyar hilly forests of Kerala, India. The collected leaves were identified and authenticated by a botanist Prof. V. Mahesh, Department of Microbiology, Marudhupandiyar College, Thanjavur, Tamil Nadu, India. The collected leaves were open-airdried under the shade, pulverized in to a moderately coarse powder (using pestle and mortar). Three hundred grams of the powered leaves were extracted with ethanol (70\%) for 48 hours. A semi-solid extract was obtained after complete elimination of alcohol under reduced pressure. The extract was stored in refrigerator until used. The extract was dissolved in distilled water just before oral administration. The yield of the extract was found to be $28 \%(\mathrm{w} / \mathrm{w})$.

\section{Induction of myocardial infarction}

The myocardial infarction was induced in experimental rats by intraperitoneal injection of isoproterenol hydrochloride $20 \mathrm{mg} / 100 \mathrm{~g}$ body weight, dissolved in physiological saline, for two consecutive days (Prabhu et al., 2005).

\section{Experimental protocol}

The rats were randomly divided onto three groups with six rats each. Group I, normal animals received with standard fed and water to allowed ad libitum throughout the experimental period. Group II, rats were orally fed $0.9 \%$ normal saline once daily for 28 days and in addition received isoproterenol $(20 \mathrm{mg} / 100 \mathrm{~g}$ body weight) on the $29^{\text {th }}$ and $30^{\text {th }}$ day at an interval of 24 hours. Group III, rats were pretreated with extract (500 $\mathrm{mg} / \mathrm{kg}$ body weight) for a period of 28 days and in addition received isoproterenol $(20 \mathrm{mg} / 100 \mathrm{~g}$ body weight) on the $29^{\text {th }}$ and $30^{\text {th }}$ day at an interval of 24 hours.

On completion of the experimental period, animals were anesthetized with thiopentone sodium $(50 \mathrm{mg} /$ $\mathrm{kg}$ ). The blood was collected with and without EDTA as anticoagulant. Plasma and serum were separated by centrifugation. Heart was excised immediately and immersed in physiological saline. It was suspended in $10 \%$ (w/v) ice-cold $0.1 \mathrm{M}$ phosphate buffer ( $\mathrm{pH} 7.4$ ) and cut into small pieces. The required amount was weighed and homogenized using a Teflon homogenizer. Tissue homogenate, plasma and serum were used for the estimation of various biochemical parameters.

\section{Biochemical analysis}

The activities of aspartate aminotransferase and alanine aminotransferase were estimated by the method of Reitman and Frankel (1957). Lactate dehydrogenase and creatine phosphokinase activities were determined by the method of King (1965) and Okinaka et al. (1961) respectively. The level of thiobarbituric acid reactive substances (TBARS) and reduced glutathione (GSH) were estimated by the method of Beuge and Aust (1978) and Moron et al. (1979). Troponin T was estimated by the method of Bhaskar and Rao (2002). The protein content was estimated by the method of Lowry et al. (1951).

\section{Statistical analysis}

Values were expressed as mean \pm SD and statistical significant differences between mean values were determined by one-way analysis of variance (ANOVA) followed by the Tukey's test for multiple comparisons (Harvey and Paige, 1998). Statistical analysis carried out by MS-Windows based graph pad Instat software (GraphPad Software, USA) 3 version was used. A value of $\mathrm{p}<0.001$ was considered statistically significant.

\section{Results}

Administration of isoproterenol caused a significant $(p<0.001)$ increase in lipid peroxidation in plasma and heart tissue of Group II rats as compared with that of Group I rats (Table I). This was paralleled by significant

\begin{tabular}{|c|c|c|c|c|}
\hline \multicolumn{5}{|c|}{ Table I } \\
\hline \multicolumn{5}{|c|}{$\begin{array}{l}\text { Levels of TBARS and reduced glutathione (GSH) } \\
\text { in plasma and heart tissue of of rats }\end{array}$} \\
\hline \multirow[t]{2}{*}{ Groups } & \multicolumn{2}{|c|}{ Plasma } & \multicolumn{2}{|c|}{ Heart } \\
\hline & TBARS & GSH & TBARS & GSH \\
\hline I & $2.8 \pm 0.2$ & $13.3 \pm 0.6$ & $0.9 \pm 0.1$ & $6.5 \pm 0.6$ \\
\hline II & $6.3 \pm 0.3^{a}$ & $9.6 \pm 0.6^{\mathrm{a}}$ & $1.9 \pm 0.1^{a}$ & $3.5 \pm 0.4^{a}$ \\
\hline III & $2.6 \pm 0.2$ & $13.7 \pm 0.7$ & $0.9 \pm 0.1$ & $6.8 \pm 0.9$ \\
\hline \multicolumn{5}{|c|}{ 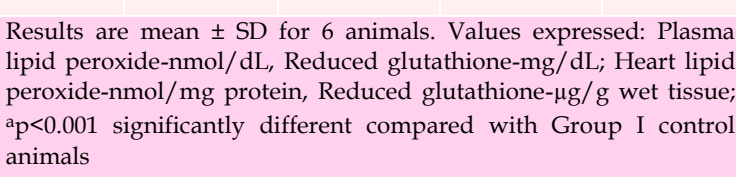 } \\
\hline
\end{tabular}

reduction in the level of reduced glutathione in the heart tissue and plasma of Group II rats as compared with that normal control rats. In Group III rats, the prior administration of $T$. zeylanicus significantly prevented the isoproterenol-induced lipid peroxidation in plasma and heart tissue and maintained the level of reduced glutathione at near normal in Group I rats. Significant $(p<0.001)$ rise observed in the activities of diagnostic marker enzymes [alanine aminotransferase (ALT), aspartate aminotransferase (AST), lactate dehydrogenase (LDH), creatine phosphokinase (CPK)] and troponin $\mathrm{T}$ in plasma (Table II) and decreased activities of ALT, AST, LDH and CPK in heart of Group II 


\begin{tabular}{|c|c|c|c|}
\hline \multicolumn{4}{|c|}{ Table II } \\
\hline \multicolumn{4}{|c|}{ Activities of biomarkers in serum of rats } \\
\hline Plasma & Group I & Group II & Group III \\
\hline ALT & $105.0 \pm 9.3$ & $278.0 \pm 33^{a}$ & $121.0 \pm 10.4$ \\
\hline AST & $92.6 \pm 9.6$ & $251.0 \pm 28.0 \mathrm{a}$ & $98.4 \pm 9.2$ \\
\hline $\mathrm{LDH}$ & $189.0 \pm 15.8$ & $292.0 \pm 29.0^{a}$ & $198.0 \pm 15.3$ \\
\hline CPK & $131.0 \pm 10.2$ & $268.0 \pm 21.0^{a}$ & $145.0 \pm 9.9$ \\
\hline \multicolumn{4}{|l|}{ Serum } \\
\hline Troponin T & $6.0 \pm 1.4$ & $12.5 \pm 2.2^{a}$ & $7.2 \pm 1.6$ \\
\hline \multicolumn{4}{|l|}{ Heart } \\
\hline ALT & $36.3 \pm 2.6$ & $16.3 \pm 1.6^{\mathrm{a}}$ & $30.5 \pm 2.1$ \\
\hline AST & $54.3 \pm 4.0$ & $38.6 \pm 3.1^{\mathrm{a}}$ & $51.2 \pm 3.8$ \\
\hline $\mathrm{LDH}$ & $248.0 \pm 10.8$ & $148.0 \pm 6.4^{\mathrm{a}}$ & $231.0 \pm 10.4$ \\
\hline CPK & $188.0 \pm 10.7$ & $124.0 \pm 8.0^{\mathrm{a}}$ & $205.0 \pm 12.5$ \\
\hline \multicolumn{4}{|c|}{$\begin{array}{l}\text { Results are mean } \pm \mathrm{SD} \text { for } 6 \text { animals; Values expressed: ALT } \\
\text { (alanine transaminase), AST (aspartate transaminase) and LDH } \\
\text { (lactate dehydrogenase)- } \mu \text { mol pyruvate liberated/hour/liter in } \\
\text { plasma and mg protein in heart; CPK- } \mu \text { mol creatine liberated/ } \\
\text { hour/liter in plasma and mg protein in heart. Troponin T-mg/dL. } \\
\text { ap }<0.001 \text { significantly different compared with Group I control } \\
\text { animals }\end{array}$} \\
\hline
\end{tabular}

myocardial infarction-induced rats as compared to Group I control animals. The pretreatment with $T$. zeylanicus significantly reduced the release of these diagnostic marker enzymes and the level of troponin $\mathrm{T}$ into the systemic circulation as compared with Group II rats.

\section{Discussion}

Lipid peroxidation has been implicated in the pathogenesis of a number of diseases include atherosclerosis, cancer etc. It is now generally accepted that lipid peroxidation and its product play an important role in liver, kidney, heart and brain toxicity (Lakshmi et al., 2005). Lipid peroxidation in vivo has been identified as one of the basic deteriorative reactions in cellular mechanisms of myocardial ischemia (Handforth, 1962). In the present results showed that the level of lipid peroxides, measure in term of TBARS was significantly increased in plasma and heart of isoproterenol-treated group. T. zeylanicus pretreatment in the present study decreases the level of plasma and myocardial lipid peroxides by an apparent direct scavenging of superoxide and hydroxyl radicals and by inactivating the enzyme cyclo-oxygenase (Singh et al., 2005).

GSH status is a highly sensitive indicator of cell functionality and viability. GSH depletion is linked to a number of disease states including cancer, neurodegenarative and cardiovascular diseases. In the present study, the reduction noticed in the level of GSH in plasma and heart of isoproterenol-induced myocardial infarction was either due to increased degradation or decreased synthesis of glutathione. Depletion of GSH results in enhanced lipid peroxidation and excessive lipid peroxidation can cause increased GSH consumption as observed in the present study. Pretreatment with $T$. zeylanicus prevented the isoproterenol-induced lipid peroxidation and maintained the level of reduced glutathione near normal level in plasma and heart. This is due to anti-oxidant activity of T. zeylanicus.

The serum enzymes creatine kinase (CK), LDH, AST, ALT and cardiac specific proteins like troponins serve as sensitive indices to assess the severity of myocardial infarction (Nigam, 2007). In this study, significant decline was shown in the activities of cardiac markers such as ALT, AST, LDH and CK in the heart of acute isoproterenol-treated rats, which is consistent with earlier reports (Kurian et al., 2005). Decreased activities of theses enzymes were due to the leakage from the damaged heart tissues into the blood stream as a result of necrosis induced by isoproterenol in rats. Senthil et al. (2007) observed that these cardio-specific marker enzymes are released from the heart into the blood during myocardial damage due to myofibril degeneration and myocyte necrosis. Significant increase was noticed in the activities of cardiac markers (SGOT, SGPT, LDH and CK) in plasma of isoproterenol -treated rats, which is consistent with earlier reports (Kurian et al., 2005), might be due to enhanced susceptibility of myocardial cell membrane to the isoproterenol mediated peroxidative damage, resulting in increased release of these diagnostic marker enzymes into the systemic circulation.

In the present study, the prior administration of $T$. zeylanicus significantly prevented the isoproterenolinduced elevation in the levels of diagnostic marker enzymes in plasma, indicating the cytoprotective activity of T. zeylanicus. Thus, it is possible that likewise $T$. zeylanicus may also prolong the viability of myocardial cell membrane stabilizing action.

Troponin $\mathrm{T}$ is a protein found in cardiac tissue. When the myocardial damage occurs, the cytosolic troponins reach the blood stream quickly resulting in a rapid peak of serum troponin (Nigam, 2007). In this study, significant increased level of troponin $\mathrm{T}$ found in serum of isoproterenol-treated rats. Increased level of troponin $\mathrm{T}$ was due to the leakage from the damaged heart tissues into the blood stream as a result of necrosis induced by isoproterenol in rats. Pretreatment with T. zeylanicus to isoproterenol-treated rats restored the level of troponin $\mathrm{T}$ in serum indicates the protective action of T. zeylanicus against peroxidative damage.

The present results clearly emphasize the beneficial action of $T$. zeylanicus as a cardioprotective herb. $T$. zeylanicus leaves proved to be effective in reducing the extent of myocardial damage, associated lipid peroxidation, thus maintaining, as suggested by biochemical indices, the structure and function of the 
myocardium. The potential cardioprotective activity of T. zeylanicus may be due to the presence of therapeutic phytochemicals and anti-oxidant action. Further studies are recommended to elucidate the mechanisms of the cardioprotective action of this plant and identification its active agent(s).

\section{References}

Beuge JA, Aust SD. The thiobarbituric acid assays. Method Enzymol. 1978; 52: 302-10.

Bhaskar I, Rao SB. New, simple and cheap alternative to troponin test for diagnosis of acute myocardial infarction. Indian J Exp Biol. 2002; 40: 628-30.

Evans DA, Subramoniam A, Rajasekharan S, Pushpangadan P. Effect of Trichopus zeylanicus Gaertn, leaf extract on the energy metabolism in mice during exercise and at rest. Indian J Pharmacol. 2002; 34: 32-37.

Handforth CP. Isoproterenol-induced myocardial infarction in animals. Arch Pathol. 1962; 73: 161-65.

Harvey J, Paige SM. The instat guide to choosing and interpreting statistical tests: A manual for graph pad instat. Version 3. San Diego, CA USA. 1998.

King J. The dehydrogenases or oxidoreductase: Lactate dehydrogenase. In: Practical clinical enzymology. Nostrand V (ed). London, 1965, p 106.

Kurian GA, Philp S, Varghese T. Effect of aqueous extract of Desmodium gangeticum DC root in the severity of myocardial infarction. J Ethanopharmcol. 2005; 97: 4557-61.

Lakshmi B, Tilak JC, Adhikari S, Devasagayam TPS, Janardhanan KK. Inhibition of lipid peroxidation induced by Gamma-radiation and AAPH in rat liver and brain mitiochondria by mushrooms. Curr Sci. 2005; 88: 484-88.

Lowry OH, Rosenbrough NJ, Farr AL, Randall RJ. Protein measurement with the Folin's reagent. J Biol Chem. 1951; 193: $265-76$.
Moron MS, DsePierre JW, Manerwik KB. Levels of glutathione, glutathione reductase and glutathione-S-transferase activities in rat lung and liver. Biochim Biophy Acta. 1979; 582: 67-68.

Nigam PK. Biochemical markers of myocardial injury. Indian J Clin Biochem. 2007; 22: 10-17.

Okinaka S, Kumaggai H, Ebashi S, Sugita H, Momoi H, Toyokura Y, Fujie Y. Serum creatine phosphokinase. Activity in progressive muscular dystrophy and neuromuscular diseases. Arch Neurol. 1961; 4: 520-25.

Prabhu S, Jainu M, Sabitha KE, Shyamala Devi CS. A beneficial effect of Maniferin on isoproterenol-induced myocardial infarction in rat model. Phcog Mag. 2005; 1: 9296.

Pushpangadan P, Rajasekharan S, Rathesh Kumar PK, Jawahar CRVNV, Lakshmi N, Amma, LS. Arogyappacha, (Trichopus zeylanicus Gaertn) The ginseng of Kani tribes of Agashtyar Hills (Kerala) for Ever Green, 1988.

Reitman S, Frankel S. A colorimetric method for the determination of serum glutamate oxaloacetic and glutamate pyruvate transaminases. Am J Clin Pathol. 1957; 28: 56-63.

Senthil S, Sridevi M, Pugalendi KV. Protective effect of Ursolic acid against myocardial ischemia induced by isoproterenol in rats. Toxicol Mechm Methd. 2007; 17: 57-65.

Sharma AK, Pushpangandan P, Chopra CL, Rajasekharan S. Adaptogenic activity of seeds of Trichopus zeylanicus Gaertn. The ginseng of Kerala. Anc Sci Life. 1989; 8: 212-19.

Singh B, Chandan BK, Sharma N, Singh S, Khajuria A, Gupta DK. Adaptogenic activity of glyco-peptido-lipid fraction from the alcoholic extract of Trichopus zeylanicus Gaerten (part II). Phytomedicine 2005; 12: 468-81.

Singh B, Gupta, DK, Chandan BK. Adaptogenic activity of a glyco-peptido-lipid fraction from the alcoholic extract of Trichopus zeylanicus Gaertn. Phytomedicine 2001; 8: 283-91.

Subramoniam A, Madhavachandra V, Rajasekharan S, Pushphangadan P. Apradosiac property of Trichopus zeylanicus in male mice. J Ethanopharmcol. 1997; 57: 21-27. 